\title{
CONVOCATORIA CONGRESO CENTROAMERICANO DE HISTORIA ORAL
}
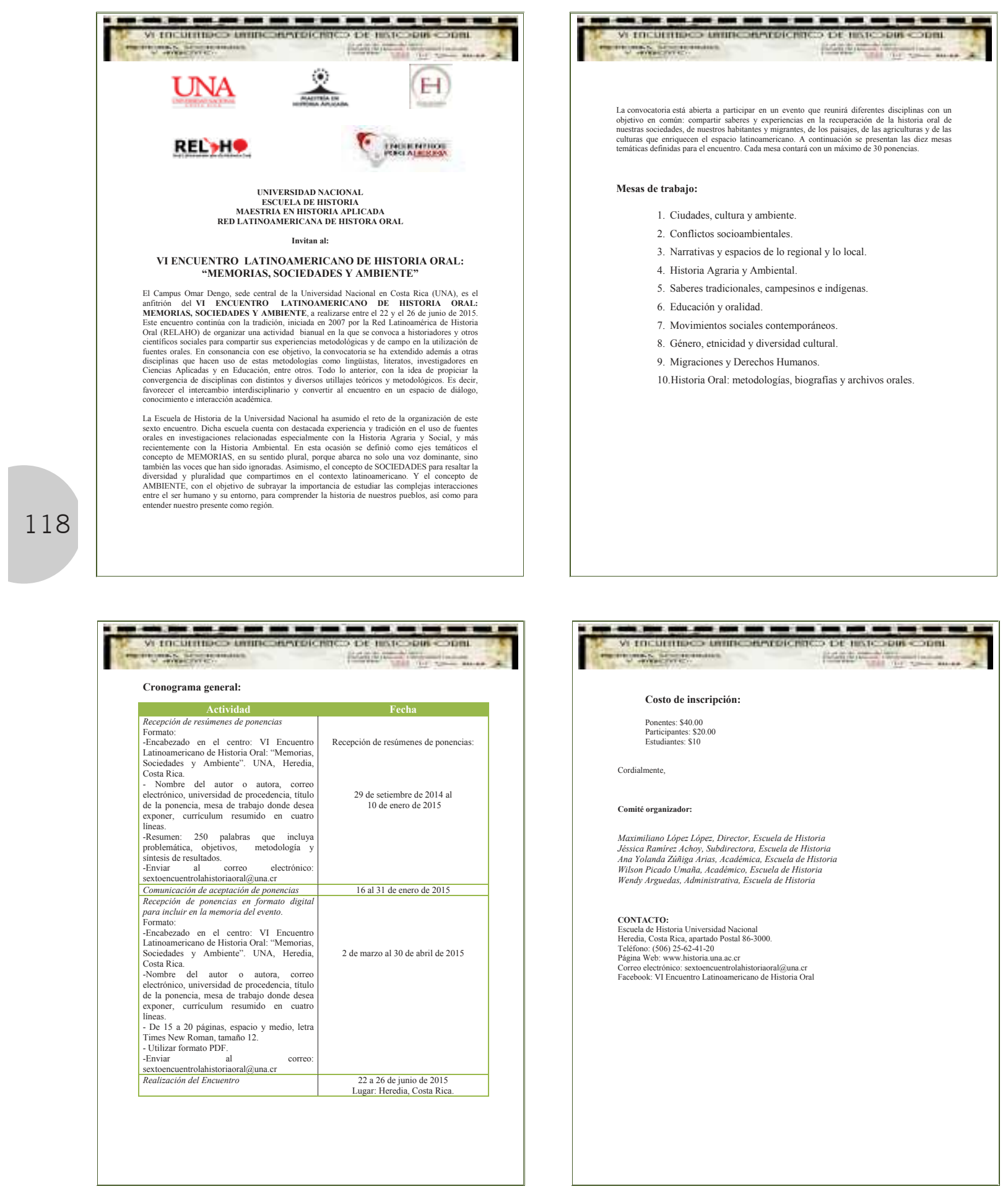

CONVOCATORIA CONGRESO CENTROAMERICANO DE HISTORIA ORAL 